\section{Characterization and Properties of Metallic Iron Nanoparticles: Spectroscopy, Electrochemistry, and Kinetics}

JAMES T. NURMI, ${ }^{\dagger}$ PAUL G. TRATNYEK, ${ }^{*}+$ VAISHNAVI SARATHY, ${ }^{\dagger}$

DONALD R. BAER, ‡

JAMES E. AMONETTE, ${ }^{\ddagger}$ KLAUS PECHER, CHONGMIN WANG, ${ }^{\ddagger}$ JOHN C. LINEHAN, DEAN W. MATSON, ${ }^{\ddagger}$ R. LEE PENN, ${ }^{\circledR}$ AND M I C H E L L E D. D R I E S S E N ${ }^{\S}$

Department of Environmental and Biomolecular Systems, Oregon Health \& Science University, 20000 NW Walker Road, Portland, Oregon 97006, Pacific Northwest National Laboratory, P.O, Box 999, Richland, Washington 99352, and Department of Chemistry, University of Minnesota, 207 Pleasant Street SE, Minneapolis, Minnesota 55455

There are reports that nano-sized zero-valent iron $\left(\mathrm{Fe}^{0}\right)$ exhibits greater reactivity than micro-sized particles of $\mathrm{Fe}^{0}$, and it has been suggested that the higher reactivity of nano- $\mathrm{Fe}^{0}$ may impart advantages for groundwater remediation or other environmental applications. However, most of these reports are preliminary in that they leave a host of potentially significant (and often challenging) material or process variables either uncontrolled or unresolved. In an effort to better understand the reactivity of nano$\mathrm{Fe}^{0}$, we have used a variety of complementary techniques to characterize two widely studied nano- $\mathrm{Fe}^{0}$ preparations: one synthesized by reduction of goethite with heat and $\mathrm{H}_{2}$ $\left(\mathrm{Fe}^{\mathrm{H} 2}\right)$ and the other by reductive precipitation with borohydride $\left(\mathrm{Fe}^{\mathrm{BH}}\right)$. $\mathrm{Fe}^{\mathrm{H} 2}$ is a two-phase material consisting of $40 \mathrm{~nm} \alpha-\mathrm{Fe}^{0}$ (made up of crystals approximately the size of the particles) and $\mathrm{Fe}_{3} \mathrm{O}_{4}$ particles of similar size or larger containing reduced sulfur; whereas $\mathrm{Fe}^{\mathrm{BH}}$ is mostly $20-80 \mathrm{~nm}$ metallic Fe particles (aggregates of $<1.5 \mathrm{~nm}$ grains) with an oxide shell/coating that is high in oxidized boron. The $\mathrm{Fe}^{\mathrm{BH}}$ particles further aggregate into chains. Both materials exhibit corrosion potentials that are more negative than nano-sized $\mathrm{Fe}_{2} \mathrm{O}_{3}, \mathrm{Fe}_{3} \mathrm{O}_{4}$, micro-sized $\mathrm{Fe}^{0}$, or a solid $\mathrm{Fe}^{0}$ disk, which is consistent with their rapid reduction of oxygen, benzoquinone, and carbon tetrachloride. Benzoquinone-which presumably probes inner-sphere surface reactions-reacts more rapidly with $\mathrm{Fe}^{\mathrm{BH}}$ than $\mathrm{Fe}^{\mathrm{H} 2}$, whereas carbon tetrachloride reacts at similar rates with $\mathrm{Fe}^{\mathrm{BH}}$ and $\mathrm{Fe}^{\mathrm{H} 2}$, presumably by outer-sphere electron transfer. Both types of nano- $\mathrm{Fe}^{0}$ react more rapidly than microsized $\mathrm{Fe}^{0}$ based on mass-normalized rate constants, but surface area-normalized rate constants do not show a significant nano-size effect. The distribution of products from reduction of carbon tetrachloride is more favorable with

\footnotetext{
* Corresponding author phone: (503)748-1023; fax: (503)748-1273; e-mail: tratnyek@ebs.ogi.edu.

Oregon Health \& Science University.

₹ Pacific Northwest National Laboratory.

$\S$ University of Minnesota.
}

$\mathrm{Fe}^{\mathrm{H} 2}$, which produces less chloroform than reaction with $\mathrm{Fe}^{\mathrm{BH}}$.

\section{Introduction}

There are many variations on the use of granular zero-valent iron metal $\left(\mathrm{Fe}^{0}\right)$ for removal of contaminants from soil and water (1). Among these, the use of nano-sized particles of $\mathrm{Fe}^{0}$ (or bimetallic combinations of $\mathrm{Fe}^{0}$ and catalytic metals such as Pd) is currently getting the most attention (2). Two potential advantages of nano-sized $\mathrm{Fe}^{0}$ over the construction-grade scrap $\mathrm{Fe}^{0}$ used in conventional permeable reactive barriers (PRBs) are that nanoparticles may be delivered to deep contamination zones by injection and that nano-sized $\mathrm{Fe}^{0}$ may be more effective at degrading some contaminants. The appeal of this technology has led to rapid adoption by the engineering community, and a number of field demonstrations have already been completed and described in the literature $(3,4)$.

There is, however, not yet consensus on a number of fundamental issues regarding the potential effectiveness of nano- $\mathrm{Fe}^{0}$ for environmental engineering applications. In particular, issues that are current subjects of research include the following: (i) the mobility of nanoparticles under subsurface conditions, (ii) the kinetics and products of contaminant degradation by nano- $\mathrm{Fe}^{0}$, and (iii) the persistence of nano- $\mathrm{Fe}^{0}$ as a reactive phase during the time period of treatment. The first issue is being addressed by others, such as those involved in the field sites noted above. With respect to the issue of reactivity, many studies have concluded that nano- $\mathrm{Fe}^{0}$ degrades contaminants more rapidly than conventional forms of granular $\mathrm{Fe}^{0}(2,5-13)$, although the basis for these comparisons has not always been clear. Another reactivity issue is that nano- $\mathrm{Fe}^{0}$ might produce different distributions of products, but this possibility does not appear to have been thoroughly investigated. On the issue of longevity, it is clear that the reactivity of nano- $\mathrm{Fe}^{0}$ suspensions can persist for at least $6-8$ weeks (14), but there does not appear to have been a detailed characterization of the "diagenesis" of nano- $\mathrm{Fe}^{0}$ or how diagenetic processes (e.g., alterations resulting from exposure to groundwater) affect reactivity with contaminants.

One reason that nano-sized $\mathrm{Fe}^{0}$ particles might exhibit greater rates of reaction with contaminants is simply that their large specific surface area provides more of the sites on which reaction occurs. For contaminants that are degraded by micro-sized $\mathrm{Fe}^{0}$-such as trichloroethylene or carbon tetrachloride-there is a well-documented dependence of contaminant reduction rate with surface area of $\mathrm{Fe}^{0}(1,15)$. However, increased surface area alone is not adequate to explain why nano- $\mathrm{Fe}^{0}$ apparently reduces some compounds that exhibit negligible reactivity with micro- $\mathrm{Fe}^{0}$ particles (such as polychlorinated biphenyls; 9,10 ). Other possible reasons why nano- $\mathrm{Fe}^{0}$ might exhibit enhanced reactivity include higher density of reactive surface sites and greater intrinsic reactivity of surface sites.

There are several reasons that smaller particle size might result in a greater density of reactive surface sites or surface sites of higher intrinsic reactivity $(16,17)$. Below about 10 $\mathrm{nm}$, properties such as the free energy and work function change significantly with particle size, following classical equations such as the Gibbs-Thompson relation between particle size and energy (18). As particle size decreases, particle dimensions approach the size of certain physical length scales-such as the electron mean-free path and the

VOL. 39, NO. 5, 2005 / ENVIRONMENTAL SCIENCE \& TECHNOLOGY • 1221 
TABLE 1. Supplier Characteristics of Iron Particles

\begin{tabular}{|c|c|c|c|c|c|c|}
\hline name & source & method & $\begin{array}{c}\text { particle } \\
\text { size } \\
\text { (dia.) }\end{array}$ & $\begin{array}{c}\text { BET } \\
\text { surface } \\
\text { area }\end{array}$ & & $\begin{array}{l}\text { minor } \\
\text { phase }\end{array}$ \\
\hline $\begin{array}{l}\mathrm{Fe}^{\mathrm{H} 2} \\
\mathrm{Fe}^{\mathrm{BH}} \\
\mathrm{Fe}^{\mathrm{EL}} \\
\mathrm{Fe}_{3} \mathrm{O}_{4} \\
\mathrm{Fe}_{2} \mathrm{O}_{3}\end{array}$ & $\begin{array}{l}\text { Toda Kogyo Corp. } \\
\text { W.-X. Zhang, Lehigh Univ. } \\
\text { Fisher Scientific } \\
\text { PNNL } \\
\text { Nanophase Technologies Corp. }\end{array}$ & $\begin{array}{l}\text { high temp. reduction of oxides with } \mathrm{H}_{2} \\
\text { precip w/ } \mathrm{NaBH}_{4} \\
\text { electrolytic } \\
\text { precip from } \mathrm{FeSO}_{4} \mathrm{w} / \mathrm{KOH} \\
\text { physical vapor synthesis (PVS) }\end{array}$ & $\begin{array}{l}70 \mathrm{~nm} \\
10-100 \mathrm{~nm} \\
150 \mu \mathrm{m} \\
30-100 \mathrm{~nm} \\
23 \mathrm{~nm}\end{array}$ & $\begin{array}{l}29 \mathrm{~m}^{2} / \mathrm{g} \\
33.5 \mathrm{~m}^{2} / \mathrm{g} \\
0.1-1 \mathrm{~m}^{2} / \mathrm{g} \\
4-24 \mathrm{~m}^{2} / \mathrm{g} \\
50 \mathrm{~m}^{2} / \mathrm{g}\end{array}$ & $\begin{array}{l}\alpha-\mathrm{Fe}^{0} \\
\mathrm{Fe}^{0} \\
99 \% \mathrm{Fe}^{0} \\
\mathrm{Fe}_{3} \mathrm{O}_{4} \\
\gamma-\mathrm{Fe}_{2} \mathrm{O}_{3}\end{array}$ & $\begin{array}{l}\text { magnetite } \\
\text { goethite, wustite }\end{array}$ \\
\hline
\end{tabular}

electron wavelength - and this results in quantum size effects that alter the electronic structure of the particle (19-21). For metal particles, quantum effects influence physical and chemical properties when the particle size is less than about $5 \mathrm{~nm}(18,22-25)$. Similar effects will arise at larger particle sizes $(10-150 \mathrm{~nm})$ for materials with lower electron density, such as oxides and semiconductors $(26,27)$. These quantum effects cause changes in the Fermi level and band gap, which can lead to increases in reactivity with decreasing particle size (28).

Nanoparticles containing $\mathrm{Fe}^{0}$ must be surrounded by some type of passivating layer-such as a shell of oxide-under environmental conditions. Although an $\mathrm{Fe}^{0}$ core may exhibit some of the quantum effects that are characteristic of entirely metallic nanoparticles, the particle as a whole will exhibit properties of the core and the shell (17). Recent studies of core-shell $\mathrm{Fe}^{0}$ nanoparticles have shown that the composition of the oxide shell-and therefore the nature of its surface sites-is influenced by particle size (29) and the particle's environment (30). In addition to the bulk composition of the shell, impurities (e.g., dopants) will affect the reactivity of particle surface (31). Furthermore, assuming that the reactivity of core-shell nanoparticles is driven by oxidation of the $\mathrm{Fe}^{0}$ core, then charge and mass transport through the shell will be necessary for sustained reaction, and the kinetics of these transport processes may be important determinants of adsorbate (contaminant) reduction kinetics.

In addition to core-shell structure, another important characteristic of reactive nanoparticles is their strong tendency to aggregate in solution. Although there are ways to form stable suspensions of dispersed nanoparticles in laboratory or engineered media (e.g., refs 32-34), aggregation of nanoparticles is difficult to avoid under environmental conditions. One consequence of the aggregation of nanoparticles into larger clusters is ambiguity regarding whether a property of the material reflects the aggregates or their nano constituents. This issue is especially important with respect to the determination of surface area because the reactive surface area of highly aggregated nanoparticles suspended in solution is likely to be very different from the surface area measured on dry, dispersed nano-sized powders.

As part of an effort to determine which of the above size and structure effects control the reactivity of nano- $\mathrm{Fe}^{0}$ under environmental conditions, we arranged to have subsamples of two types of nano- $\mathrm{Fe}^{0}$ characterized by a comprehensive array of complementary methods. The two types of nanoparticles used in this study were selected because they represent distinct and prototypical methods of synthesis, and they have been used in both laboratory and field studies for contaminant degradation. The methods used to characterize these particles gave size, shape, surface area, composition and crystallinity of the bulk and surface material, corrosion potential, and reactivity with respect to two model contaminants (benzoquinone and carbon tetrachloride). The study demonstrates both similarities and fundamental differences in the physical structure and reaction pathways of the two types of nano-sized iron particles.

By necessity, this study also addresses some of the many methodological issues associated with the study of highly reactive nano-sized materials that change over time, with handling, and during analysis. Because nano- $\mathrm{Fe}^{0}$ is often stabilized for distribution in aqueous suspensions or pastes and these materials do not allow accurate and reproducible dispensation of quantities of particles for experimentation, we investigated a procedure we call "flash-drying" to remove water (and associated solutes) while minimizing other changes in the particle composition. Another major methodological issue that we address is the determination of the particle surface area that is relevant to quantifying their reactivity in solution. This issue proved to be a major obstacle in making quantitative comparisons of reactivity among nano- and micro-sized $\mathrm{Fe}^{0}$ particles.

\section{Experimental Section}

Reagents. All chemicals were obtained in high purity and were used as received, including boric acid (Fisher, Certified ACS), sodium borate (Fisher, Certified ACS), benzoquinone (Acros, 99+\%), hydroquinone (Fisher, laboratory grade), $N$ - [2hydroxyethyl] piperazine- $N^{\prime}$ - [3-propanesulfonic acid] (Sigma, 99.5\%), carbon tetrachloride (Sigma, HPLC grade), chloroform (Sigma, HPLC grade), and argon (Airgas, UHP). All stock solutions were prepared with $\mathrm{N}_{2}$-sparged deionized water and stored in an anaerobic chamber. Borate buffer ( $\mathrm{pH}$ 8.4) was made from $0.15 \mathrm{M} \mathrm{H}_{3} \mathrm{BO}_{3}$ and $0.0375 \mathrm{M} \mathrm{Na}_{2} \mathrm{~B}_{4} \mathrm{O}_{7}$. EPPS buffer was made from $0.01 \mathrm{M} N$-[2-hydroxyethyl]piperazine$N^{\prime}$-[3-propanesulfonic acid], by titrating with $\mathrm{NaOH}$ to $\mathrm{pH}$ 8.4.

Iron Samples. The iron and iron oxide powders characterized in this study were from five sources. Characteristics provided by the suppliers are summarized in Table 1. Nanosized metallic iron was obtained from Toda Kogyo Corp. (Schaumberg, IL) and W.-X. Zhang (Lehigh University). The material from Toda $\left(\mathrm{Fe}^{\mathrm{H} 2}\right)$ was the commercial product known as RNIP-10DS, which is produced by reduction of goethite and hematite particles with $\mathrm{H}_{2}$ at high temperatures (200$600{ }^{\circ} \mathrm{C}$ ) (35). Two samples of this material were received and proved to be similar, but all the data presented here are from the second lot. $\mathrm{Fe}^{\mathrm{H} 2}$ is known to be a two-phase material consisting of $\mathrm{Fe}_{3} \mathrm{O}_{4}$ and $\alpha-\mathrm{Fe}^{0}$ (35); however, no effort was made to ensure "uniform" mixing of the two phases. This material has been used in previous laboratory studies $(9,36)$ and at least one field test (37). The material from Zhang $\left(\mathrm{Fe}^{\mathrm{BH}}\right)$ was synthesized by reductive precipitation of $\mathrm{FeCl}_{3}$ with $\mathrm{NaBH}_{4}$ (5). Three different batches of this material were provided, and they proved to be substantially similar. This material should be similar to the nano- $\mathrm{Fe}^{0}$ used by Zhang in previous laboratory studies $(5,6,8)$ and at least one field test $(3,38)$. Other recent studies that have used nano- $\mathrm{Fe}^{0}$ prepared by reductive precipitation with $\mathrm{NaBH}_{4}$ include refs $9,12,34$, and $39-41$.

Nano-sized magnetite $\left(\mathrm{Fe}_{3} \mathrm{O}_{4}\right)$ was synthesized by rapid thermal decomposition of solutes (RTDS), a flow-through hydrothermal method $(42,43)$. Maghemite $\left(\mathrm{Fe}_{2} \mathrm{O}_{3}\right)$ was purchased from Nanophase Technologies Corp. (Romeoville, IL, Catalog No. Fe-0800-007-025). The micro-sized electrolytic $\mathrm{Fe}^{0}$ powder $\left(\mathrm{Fe}^{\mathrm{EL}}\right)$ was from Fisher (Pittsburgh, PA, 99\%, Catalog No. I60-3). Nano iron powders were not sieved or 
polished before use. Some experiments were performed with nano iron powders that were flash-dried by rinsing with acetone/water during suction filtration (as described previously; 44), because preliminary experiments suggested that this process can facilitate sample handling and increase reproducibility without significantly altering the reactivity of the particles. Except where noted otherwise, all handling of these materials was done under anoxic conditions (e.g., in an anoxic chamber containing $5 \% \mathrm{H}_{2}$ in $\mathrm{N}_{2}$ ). The $\mathrm{Fe}^{\mathrm{EL}}$ was seived with a 200 mesh seive, and the fines were discarded. The remaining iron powder (100-200 mesh) was then washed with water, ultrasonicated for 15 min until the supernatant water showed no color or turbidity (3 times was always sufficient), and then flash-dried. The resulting material was stored under anoxic conditions.

Transmission Electron Microscopy (TEM). High-resolution TEM was performed using either a JEOL JEM 2010F operated at $200 \mathrm{kV}$ or a Tecnai 12ST (Cs of $2 \mathrm{~mm}$ ) operated at $120 \mathrm{kV}$. All images were digitally recorded using slow scan $1024 \times 1024$ CCD cameras and processed using Digital Micrograph (Gatan). Pre-reaction samples were mounted on carbon-coated TEM grids in an anaerobic chamber but were exposed to air briefly during transfer from the anaerobic chamber to the microscope. Prior to insertion into the microscope, post-reaction samples were mounted on carboncoated TEM grids inside an anaerobic glovebag.

X-ray Photoelectron Spectroscopy (XPS). Samples for XPS were mounted on double-sided adhesive tape in an anaerobic chamber and transferred into the instrument without exposure to air via a $\mathrm{N}_{2}$-purged glovebag attached to the sample entry system. The XPS measurements were performed using a Physical Electronics Quantum 2000 scanning ESCA microprobe with a focused monochromatic Al K $\alpha$ X-ray (1486.7 eV) source for excitation, a spherical section analyzer, and a 16-element multichannel detection system. The X-ray beam was $105 \mathrm{~W}$ with a $100 \mu \mathrm{m}$ spot rastered over a $1.4 \mathrm{~mm} \times 0.2 \mathrm{~mm}$ rectangle on the sample surface. The X-ray beam was incident normal to the sample, and the X-ray photoelectron detector was at $45^{\circ}$ off normal. Data were collected using a pass energy of $23.5 \mathrm{eV}$. For the Ag 3d5/2 line, these conditions produced a full-width at halfmaximum (fwhm) of $0.77 \mathrm{eV}$. The binding energy scale was calibrated using the $\mathrm{Cu} 2 \mathrm{p} 3 / 2$ feature at $932.62 \pm 0.05 \mathrm{eV}$ and $\mathrm{Au} 4 \mathrm{f}$ at $83.96 \pm 0.05 \mathrm{eV}$ for known standards. The $1 \mathrm{eV}, 20$ $\mathrm{uA}$ electrons, and low energy $\mathrm{Ar}^{+}$ions were used to minimize charging.

X-ray Diffraction (XRD). Specimens were prepared for $\mathrm{XRD}$ analysis by spreading $\sim 25 \mathrm{mg}$ of $\mathrm{Fe}^{\mathrm{H} 2}$ or $\mathrm{Fe}^{\mathrm{BH}}$ on a zerobackground slide and allowing it to dry for 2-3 days in an anaerobic chamber that was constantly purged with $\mathrm{N}_{2}$. The dried specimens were protected from oxygen by applying a few drops of $10 \%$ glycerol in $95 \%$ ethanol and allowed to dry for 1-2 more days. The glycerol-coated specimens were then analyzed in ambient air with $\mathrm{Cu} K \alpha$ radiation using a Philips X'Pert MPD diffractometer (PW3040/00) operated at 40 KVP and $50 \mathrm{~mA}$. Continuous scans from 2 to $75^{\circ} 2 \theta$ were collected at a scan rate of about $2.4^{\circ} 2 \theta \mathrm{min}^{-1}$. Successive scans, as well as scans taken after $24 \mathrm{~h}$ of exposure to ambient air, showed no change in the structural properties of the glycerolcoated specimens, verifying the protective effect of the glycerol film with respect to oxidation. The mean crystallite dimension was estimated using the Scherrer equation, after correction for instrumental broadening.

Scanning Transmission X-ray Microscopy (STXM). X-ray absorption measurements were done at the Advance Light Source (Lawrence Berkeley National Laboratory) on beam line 11.0.2. For end station and beam line details, see http:// www-als.lbl.gov/als/microscopes/scope11.0.2.html. All samples were prepared inside an anaerobic chamber $(<0.1 \mathrm{ppm}$ $\mathrm{O}_{2}$ ) by dipping carbon-coated TEM grids into dried powder samples and mounting the grids onto aluminum sample holders. Transfer of these holders into the microscope resulted in short $(<30 \mathrm{~s})$ exposure of the sample to air. Details regarding the methods used for data acquisition and analysis have been described previously (45).

Surface Area by Gas Adsorption. BET (BrunauerEmmett-Teller) surface areas were determined from $\mathrm{N}_{2}$ physisorption with an RXM-100 advanced catalyst characterization system (ASDI, Inc), using the BJH (Barrett-JoynerHalenda) and multi-point BET methods. Samples were loaded in a anaerobic chamber and evacuated at specified temperatures between 50 and $150{ }^{\circ} \mathrm{C}$ for $4 \mathrm{~h}$ before each measurement.

Electrochemical Experiments. Powder disk electrodes (PDEs) were prepared by pressing the powders into the electrode cavity (this compression was sufficient to hold most Fe powders in the cavity). Details of the design and application of these electrodes, including extensive validation and analysis of their response with $\mathrm{Fe}^{\mathrm{EL}}$, has been reported previously (46). In this study, we used only high purity iron as the underlying disk material, to avoid any possibility of galvanic processes. Electrode potentials and currents were recorded with a potentiostat (Autolab PGSTAT30, EcoChemie, Utrecht, The Netherlands). Electrochemical experiments were performed using the methods, solutions, and electrodes described above in various permutations. All potentials are reported relative to a $\mathrm{Ag} / \mathrm{AgCl}$ reference, and currents are reported in accord with IUPAC convention (anodic currents are positive and cathodic currents are negative). All polarization experiments were done at a scan rate of $0.1 \mathrm{mV} / \mathrm{s}$, which should give approximately steady-state conditions at the working electrode (47).

Batch Experiments (Benzoquinone). Benzoquinone (BQ) batch experiments were performed in an anaerobic chamber with a $3.4 \% \mathrm{H}_{2}$ in $\mathrm{N}_{2}$ atmosphere. Particle samples (flashdried $\mathrm{Fe}^{\mathrm{BH}}$, flash-dried $\mathrm{Fe}^{\mathrm{H} 2}$, and as-received $\mathrm{Fe}^{\mathrm{EL}}$ ) were weighed into $40-\mathrm{mL}$ amber reaction vials and suspended in $20.0 \mathrm{~mL}$ of deoxygenated, deionized water. After $\geq 4 \mathrm{~h}$ exposure, $5.0 \mathrm{~mL}$ of BQ stock solution was added to each of the reaction vials (final concentration $=0.2-2 \mathrm{mM}$ ). The vials were sealed and removed from the anaerobic chamber and placed on a shaker table $(200 \mathrm{rpm})$. Periodically, vials were moved back into the anaerobic chamber and sampled for analysis by high-performance liquid chromatography (HPLC). HPLC was done with a Sorbax C18 StableBond column (at $\left.30^{\circ} \mathrm{C}\right), 40 \mathrm{mM}$ aqueous acetate buffer (pH 5) and $\sim 35 \%$ acetonitrile, with a UV-absorbance detector at $\lambda=235$ $\mathrm{nm}$.

Batch Experiments (Carbon Tetrachloride). Three complementary procedures were used for the batch experiments with carbon tetrachloride (CT). The first was optimized for routine determination of CT disappearance kinetics and the yield of chloroform (CF); the second gave full time-series data on all products and, therefore, mass balance but was only done for a few samples of $\mathrm{Fe}^{0}$; and the third gave the yield of all products and mass balance readily but without the time-series data needed for full kinetic analysis.

For the first and second procedures, experiments were performed in well-mixed, $120-\mathrm{mL}$, zero-headspace reactors. Target quantities of $\mathrm{Fe}^{0}$ ( $3.00 \mathrm{~g} \mathrm{Fe}^{\mathrm{EL}}, 0.15$ or $0.30 \mathrm{~g} \mathrm{Fe}^{\mathrm{H} 2}$, and 0.15 or $\left.0.30 \mathrm{~g} \mathrm{Fe}^{\mathrm{BH}}\right)$ were selected to give roughly equal surface areas $\left(\sim 6 \mathrm{~m}^{2} \mathrm{~L}^{-1}\right)$. The $\mathrm{Fe}^{0}$ was exposed to deoxygenated, deionized water or buffer for $24 \mathrm{~h}$, and then CT-saturated deoxygenated water was added to give an initial CT concentration $\left(\mathrm{C}_{0}\right)$ of $4.0 \mu \mathrm{M}$ for the first procedure and $862 \mu \mathrm{M}$ for the second procedure. During reaction, vials were covered with foil to exclude light, and they were mixed on a rotary shaker at $24 \mathrm{rpm}$ at room temperature $\left(\sim 22{ }^{\circ} \mathrm{C}\right)$. Samples were taken periodically and analyzed for $\mathrm{CT}, \mathrm{CF}, \mathrm{HCOO}^{-}$, and $\mathrm{Cl}^{-}$. Controls were prepared without $\mathrm{Fe}^{0}$ (for leakage of 
TABLE 2. Summary of Physical Properties

\begin{tabular}{|c|c|c|c|c|c|c|c|}
\hline name & $\begin{array}{l}\text { sample } \\
\text { history }\end{array}$ & $\begin{array}{l}\text { mean particle } \\
\text { size from } \\
\text { TEM (nm) }\end{array}$ & $\begin{array}{l}\text { shell } \\
\text { thickness } \\
\quad(\mathrm{nm})\end{array}$ & TEM structure & $\begin{array}{l}\text { XRD } \\
\text { (grain } \\
\text { size } \mathrm{nm} \text { ) }\end{array}$ & XPS & STXM \\
\hline $\mathrm{Fe}^{\mathrm{H} 2}$ & as-received & $\begin{array}{l}\sim 38 \mathrm{Fe}^{0} \\
>60 \mathrm{~nm} \mathrm{Fe}-\mathrm{Ox} \\
\quad \text { plates }\end{array}$ & $\sim 3.4 \mathrm{FeOx}$ & $\begin{array}{l}\text { "large" plates (oxide) and smaller } \\
\mathrm{Fe}^{0} \text { irregularly shaped } \\
\text { particles with crystalline } \\
\text { oxide shell }\end{array}$ & $\begin{array}{l}\mathrm{Fe}^{0}(\sim 30) \\
\quad \mathrm{FeOx}(\sim 60)\end{array}$ & $\mathrm{Fe}^{0}+\mathrm{Fe}^{3+}$ & $\begin{array}{l}\mathrm{Fe}^{0}+ \\
\mathrm{FeOx}\end{array}$ \\
\hline $\mathrm{Fe}^{\mathrm{H} 2}$ & flash-dried & $\sim 44 \mathrm{Fe}^{0}$ & & as above with more large plates & & less $\mathrm{Fe}^{0}$ & \\
\hline $\mathrm{Fe}^{\mathrm{BH}}$ & as-received & $\begin{array}{l}\sim 59 \\
\text { size range } \\
(20-100)\end{array}$ & $\sim 2.3$ & $\begin{array}{l}\text { three levels of structure: } \\
\text { (i) small crystallites }<1.5 \mathrm{~nm} \\
\text { (ii) } 20-100 \mathrm{~nm} \text { spherical } \\
\text { aggregates with an } \\
\text { amorphous coating } \\
\text { (iii) chains of } 20-100 \mathrm{~nm} \text { particles }\end{array}$ & $\begin{array}{c}\text { mostly } \mathrm{Fe}^{0} \\
(<1.5)\end{array}$ & $\begin{array}{l}\mathrm{Fe}^{0}+\mathrm{Fe}^{3+} \\
+\mathrm{B} \\
\text { and } \mathrm{Na}\end{array}$ & $\begin{array}{l}\text { mostly } \\
\mathrm{Fe}^{0}\end{array}$ \\
\hline $\mathrm{Fe}^{\mathrm{BH}}$ & flash-dried & $\begin{array}{l}\sim 67 \\
\text { size range } \\
(20-100)\end{array}$ & $\sim 3.2$ & as above with thicker coating & & $\begin{array}{l}\text { less } \mathrm{Fe}^{0}+ \\
\mathrm{B} \text { and } \\
\mathrm{Na}\end{array}$ & \\
\hline
\end{tabular}

CT or volatile products) and without CT (for leaching of $\mathrm{HCOO}^{-} \mathrm{or}^{-}$). Concentrations of CT and CF were measured by gas chromatography with a headspace autosampler, DB624 column, and electron capture detector. Chloride was analyzed using ion chromatography, using an Allsep Anion A2 column with carbonate-based eluant. Formate was analyzed with an assay based on photoluminescence, as described elsewhere (48). Methane and carbon monoxide were detected by headspace analysis using gas chromatography with thermal conductivity detection with a GSGASPRO capillary column operated at $-80{ }^{\circ} \mathrm{C}$.

For the third procedure, experiments were performed in 12-mL headspace reactors. Target quantities of each sample (10 mg) were exposed to deoxygenated deionized water overnight. Then, CT-saturated deoxygenated water was added (giving initial concentrations of $2.4 \mathrm{mM} \mathrm{CT}$ and $0.2 \mathrm{~g} \mathrm{~L}^{-1}$ $\mathrm{Fe}^{0}$ ), the vials were crimp-sealed with Teflon-lined septa, and the sealed vials were gently agitated in the dark using a mechanical shaker until analysis. Concentrations of chlorinated methane species were analyzed by gas chromatography with a DB-1 column and a mass spectrometric detector. Analysis for non-chlorinated gas species was performed with gas chromatography using thermal conductivity detection (TCD).

\section{Results and Discussion}

Structure and Composition. Particle shape, size, and composition are important properties that affect the chemical and physical properties of nanoparticles. To provide primary characterization of these properties, XRD, TEM, and XPS measurements were made on specimens of $\mathrm{Fe}^{\mathrm{H} 2}$ and $\mathrm{Fe}^{\mathrm{BH}}$, as received and after flash-drying. In addition, STXM and BET measurements were made on selected samples. The results of these analyses are summarized in Table 2.

$\mathrm{XRD}$ on the as-received $\mathrm{Fe}^{\mathrm{H} 2}$ showed two phases, $\alpha-\mathrm{Fe}^{0}$ and $\mathrm{Fe}_{3} \mathrm{O}_{4}$, with the proportion of metal and oxide ranging from 70 to $30 \%$ metal (and from 30 to $70 \%$ oxide). The proportions of $\alpha-\mathrm{Fe}^{0}$ and $\mathrm{Fe}_{3} \mathrm{O}_{4}$ agree well with the manufacturer's description of this product (35). The mean crystallite dimension (from the Scherrer equation) for the metal grains was $\sim 30 \mathrm{~nm}$ while that for the oxide was $\sim 60 \mathrm{~nm}$. In contrast, $\mathrm{Fe}^{\mathrm{BH}}$ yielded very broad peaks for $\alpha-\mathrm{Fe}^{0}$ with mean crystallite dimensions $<1.5 \mathrm{~nm}$. The non-Lorentzian shape of these peaks (Supporting Information, Figure S1) suggests a distribution of crystallite dimensions. In addition to the much smaller crystallite size, the XRD patterns for $\mathrm{Fe}^{\mathrm{BH}}$ differ from those for $\mathrm{Fe}^{\mathrm{H} 2}$ by having no reflections for oxide phases. Flashdrying had essentially no effect on the XRD patterns for both $\mathrm{Fe}^{\mathrm{H} 2}$ and $\mathrm{Fe}^{\mathrm{BH}}$.

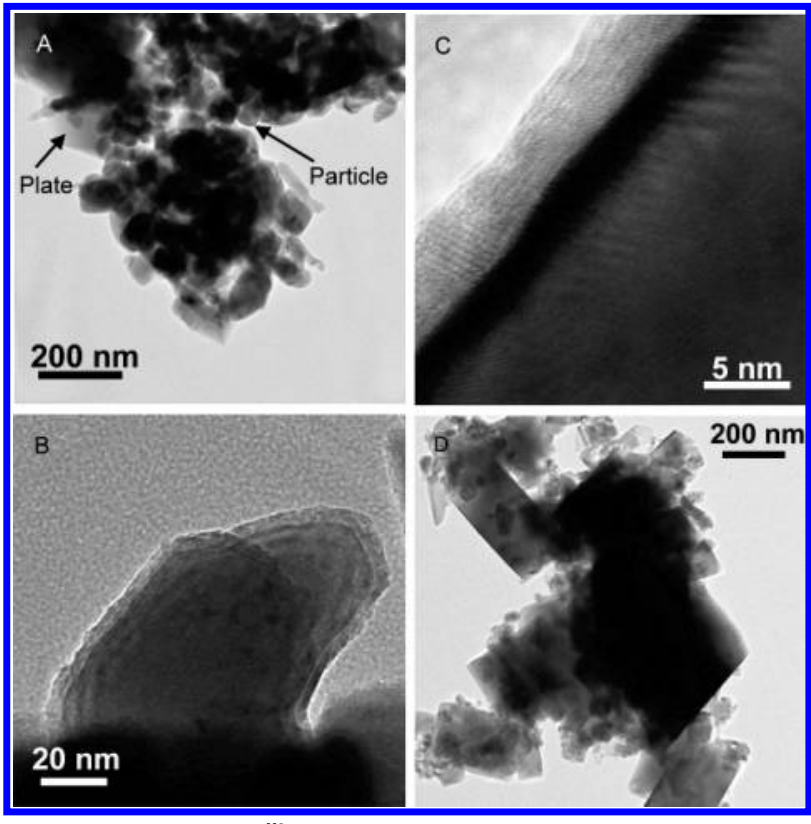

FIGURE 1. TEMs of Fe $\mathrm{H}^{\mathrm{H} 2}$. (A) Low magnification image of as-received sample. (B) Higher resolution image of irregularly shaped metal particle. (C) Higher resolution image of oxide shell around metal particle. (D) Low resolution image of flash-dried sample.

The TEM data (Figure 1A) show that as-received $\mathrm{Fe}^{\mathrm{H} 2}$ is composed of aggregates of faceted plates and smaller irregular particles. The plates-which appear to be oxide-are usually larger than the particles and vary in size and quantity. The small irregularly shaped particles consist of a nearly singlecrystal $\mathrm{Fe}^{0}$ core with a polycrystalline oxide shell, as shown in Figure $1 \mathrm{~B}, \mathrm{C}$. Flash-dried $\mathrm{Fe}^{\mathrm{H} 2}$ is similar, except that more large oxide plates are shown in Figure 1D (however, this difference could be due to sampling bias).

The TEM images of the three batchs of $\mathrm{Fe}^{\mathrm{BH}}$ appear similar to one another (Figure 2). The material is comprised of $<1.5$ $\mathrm{nm}$ crystals that are aggregated into approximately spherical 20-100 nm diameter particles, and these particles are further aggregated into the chains shown in Figure 2A. Electron diffraction from the particle cores indicates that the cores are made up of either very small grains or are amorphous. For several particles, however, small discrete spots are visible on the diffraction patterns, which indicate crystalline material (Figure 2B,C). Dark-field imaging (Figure 2C) of these particles clearly reveals crystallites that are only a few nanometers in size. This is consistent with the average crystallite size of $<1.5 \mathrm{~nm}$ measured from diffraction peak broadening in the 


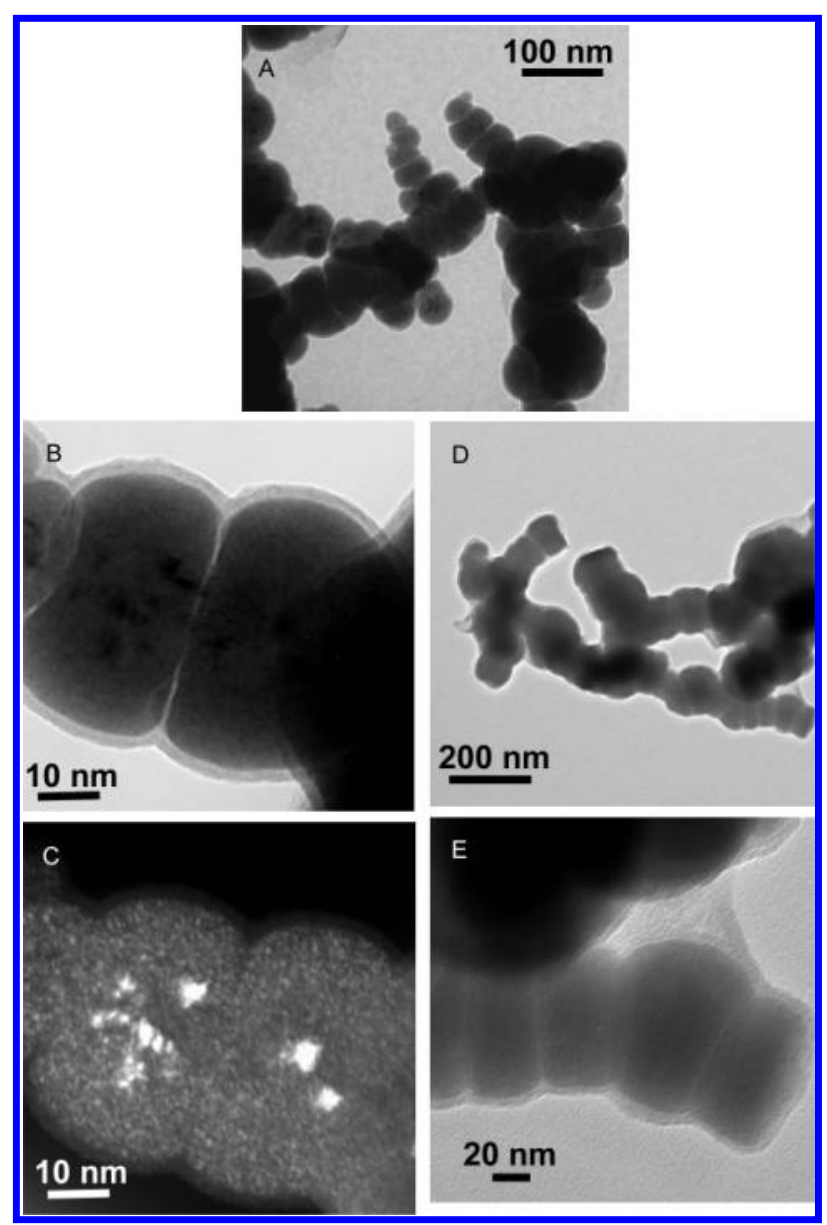

FIGURE 2. TEMs of $\mathrm{Fe}^{\mathrm{BH}}$. (A) Low magnification image of as-received sample. (B) Higher resolution image of metal particle. (C) Dark field image of metal particle highlighting small metal crystallites in particle. (D) Low resolution image of flash-dried sample. (E) Higher resolution image of flash-dried sample showing spreading of coating layer between particles.

XRD data. The spherical particles appear to be coated with a shell of apparently amorphous material, which partially decomposed after 1 min under the $200 \mathrm{~V}$ electron beam of the TEM (Supporting Information, Figure S2). Flash-dried $\mathrm{Fe}^{\mathrm{BH}}$ is similar to as-received $\mathrm{Fe}^{\mathrm{BH}}$, except for variations in the distribution of the material coating the particles (Figure 2D,E).

The TEM images were used to determine particle size (Supporting Information, Figure S3), from which specific surface areas $\left(\rho_{\mathrm{a}}, \mathrm{m}^{2} \mathrm{~g}^{-1}\right)$ were calculated assuming that the particles have spherical geometry and density equal to that of $\mathrm{Fe}^{0}\left(7.68 \mathrm{~g} \mathrm{~cm}^{-3}\right)$. For $\mathrm{Fe}^{\mathrm{H} 2}$, the average particle size was $38 \mathrm{~nm}$ as received and $45 \mathrm{~nm}$ after flash-drying. Calculating $\rho_{\mathrm{a}}$ for each particle and averaging gives 25 and $33 \mathrm{~m}^{2} \mathrm{~g}^{-1}$, respectively. However, because the particle size distributions are skewed by a small number of large particles (they appear to be log-normally distributed, Figure S3), smaller estimates of $\rho_{\mathrm{a}}$ ( 11 and $3.5 \mathrm{~m}^{2} \mathrm{~g}^{-1}$, respectively) are obtained by dividing the total surface area of the particles by their (calculated) mass. This procedure is comparable to the property that is measured by BET gas adsorption, and the value of $\rho_{\mathrm{a}}$ calculated from total surface area agrees well with the value we measured for flash-dried $\mathrm{Fe}^{\mathrm{H} 2}$ by BET $\left(3 \mathrm{~m}^{2} \mathrm{~g}^{-1}\right)$. The calculated values of $\rho_{\mathrm{a}}$ are inversely proportional to the assumed density of the particles, so using the average density of magnetite and $\mathrm{Fe}^{0}\left(\approx 6.7 \mathrm{~g} \mathrm{~cm}^{-3}\right)$ would increase the estimated values of $\rho_{\mathrm{a}}$ by $14 \%$. Overall, our values are consistent with the low end of the range of BET-determined
TABLE 3. Particle Surface Compositions Determined by XPSa

\begin{tabular}{|c|c|c|c|c|c|c|c|}
\hline & $\mathrm{Fe} / 0$ & $\mathrm{Fe}$ & 0 & B & $\mathrm{Na}$ & $\mathbf{S}$ & $\mathrm{Ca}$ \\
\hline \multicolumn{8}{|c|}{$\mathrm{Fe}^{\mathrm{H} 2}$} \\
\hline as-received (fresh) & 1.15 & 50.9 & 44.2 & 0.0 & 3.0 & 1.9 & 0.0 \\
\hline air-exposed & 0.89 & 45.7 & 51.5 & 0.0 & 1.7 & 1.1 & 0.0 \\
\hline as-received (aged) & 0.72 & 37.9 & 52.3 & 0.0 & 8.1 & 1.3 & 0.4 \\
\hline flash-dried & 0.85 & 45.0 & 52.9 & 0.0 & 0.7 & 0.9 & 0.5 \\
\hline \multicolumn{8}{|c|}{$\mathrm{Fe}^{\mathrm{BH}}$} \\
\hline as-received (fresh) & 0.41 & 20.0 & 49.1 & 16.0 & 14.5 & 0.5 & 0.0 \\
\hline air-exposed & 0.40 & 23.5 & 59.2 & 12.0 & 4.8 & 0.5 & 0.0 \\
\hline as-received (aged) & 0.56 & 29.2 & 52.4 & 16.2 & 2.2 & 0.0 & 0.0 \\
\hline flash-dried & 0.55 & 30.8 & 56.4 & 12.3 & 0.5 & 0.0 & 0.0 \\
\hline${ }^{a}$ In atomic $\%$. & & & & & & & \\
\hline
\end{tabular}

$\rho_{\mathrm{a}}$ values given by the manufacturer of $\mathrm{Fe}^{\mathrm{H} 2}\left(4-60 \mathrm{~m}^{2} \mathrm{~g}^{-1}\right.$; 35).

For $\mathrm{Fe}^{\mathrm{BH}}$, the TEM data gave average particles sizes of 59 and $67 \mathrm{~nm}$, for the as-received and flash-dried samples, respectively (Figure S3). Calculating $\rho_{\mathrm{a}}$ for each measured particle and averaging gives 19 and $14 \mathrm{~m}^{2} \mathrm{~g}^{-1}$; whereas, dividing the total surface area of the particles by their mass gives $\rho_{\mathrm{a}}=7$ and $8.5 \mathrm{~m}^{2} \mathrm{~g}^{-1}$. The latter value agrees well with the value of $\rho_{\mathrm{a}}$ that we measured for flash-dried $\mathrm{Fe}^{\mathrm{BH}}$ by BET gas adsorption $\left(5 \mathrm{~m}^{2} \mathrm{~g}^{-1}\right)$. Even if a particle density closer to that of magnetite is assumed in the calculations, our estimates of $\rho_{\mathrm{a}}$ for $\mathrm{Fe}^{\mathrm{BH}}$ are lower than the BET-determined values that have been reported previously for this material $\left(33.5-35 \mathrm{~m}^{2}\right.$ $\left.\mathrm{g}^{-1} ; 5,8\right)$.

XPS showed that the $\mathrm{Fe}^{\mathrm{H} 2}$ surfaces are made up of mostly Fe and $\mathrm{O}$ with small amounts of $\mathrm{S}, \mathrm{Na}$, and $\mathrm{Ca}$ (Table 3 ). The presence of sulfur is expected due to the use of $\mathrm{FeSO}_{4}$ as a precursor in the synthesis of this product, and the manufacturer claims that reduced S plays an important role its reactivity (35). The Fe/O ratio observed by XPS varied from 0.72 to 1.15 , which is consistent with a mixture of metallic iron and iron oxide (cf., the $\mathrm{Fe} / \mathrm{O}$ ratio for $\mathrm{Fe}_{2} \mathrm{O}_{3}$, which would be $\sim 0.67$ ). In contrast to the composition of $\mathrm{Fe}^{\mathrm{H} 2}, \mathrm{Fe}^{\mathrm{BH}}$ contains significantly less $\mathrm{Fe}$ and $\mathrm{S}$, more $\mathrm{B}$, and the $\mathrm{Fe} / \mathrm{O}$ ratio varies from 0.4 to 0.55 . The relative amounts of $\mathrm{Fe}, \mathrm{O}$, $\mathrm{B}$ and $\mathrm{Na}$ appear to be consistent with the presence of a metal core, a thin iron oxide layer, and an outer layer that is predominantly a sodium borate phase. The XPS spectra of the as-received samples of $\mathrm{Fe}^{\mathrm{BH}}$ suggest mostly oxidized B (borate) with some reduced B (boride), as might be expected based on previous work showing that iron borides can be formed from reduction of aqueous $\mathrm{Fe}^{2+}$ with borohydride (49). In the air-exposed and flash-dried samples, the surface contained less $\mathrm{Na}$ than $\mathrm{B}$, but the data are still consistent with a borate component in the shell. Most of the B we see is located in the surface layer of the particles, as has been observed previously (50); however, others have described $\mathrm{Fe}^{\mathrm{BH}}$ type particles as doped with B (9), and our measurements do not exclude that possibility.

The Fe 2p XPS data give $\mathrm{Fe}^{0}$ and iron oxide peaks for $\mathrm{Fe}^{\mathrm{H} 2}$ and $\mathrm{Fe}^{\mathrm{BH}}$ (Supporting Information, Figure S4). We have not attempted to quantify the ratios of $\mathrm{Fe}^{2+}$ and $\mathrm{Fe}^{3+}$ from these spectra, but it is evident from the data presented in Table 3 that the ratio of $\mathrm{Fe}^{0}$ to oxide signal varies with the sample type and history. Because XPS is sensitive to the outer 3-5 $\mathrm{nm}$ of the particles, the presence of a peak for $\mathrm{Fe}^{0}$ confirms that the shell is less than a few nanometers thick. Exposure of the nanoparticles to air caused the $\mathrm{Fe}^{0}$ peak in the XPS spectra to decrease or disappear. Flash-drying decreased the $\mathrm{Fe}^{0}$ to oxide signal strength, but $\mathrm{Fe}^{0}$ was always present. It may prove to be significant that the $\mathrm{S}$ on the $\mathrm{Fe}^{\mathrm{BH}}$ is in an oxidized form while the $\mathrm{S}$ on the $\mathrm{Fe}^{\mathrm{H} 2}$ appears to be in a reduced form. 


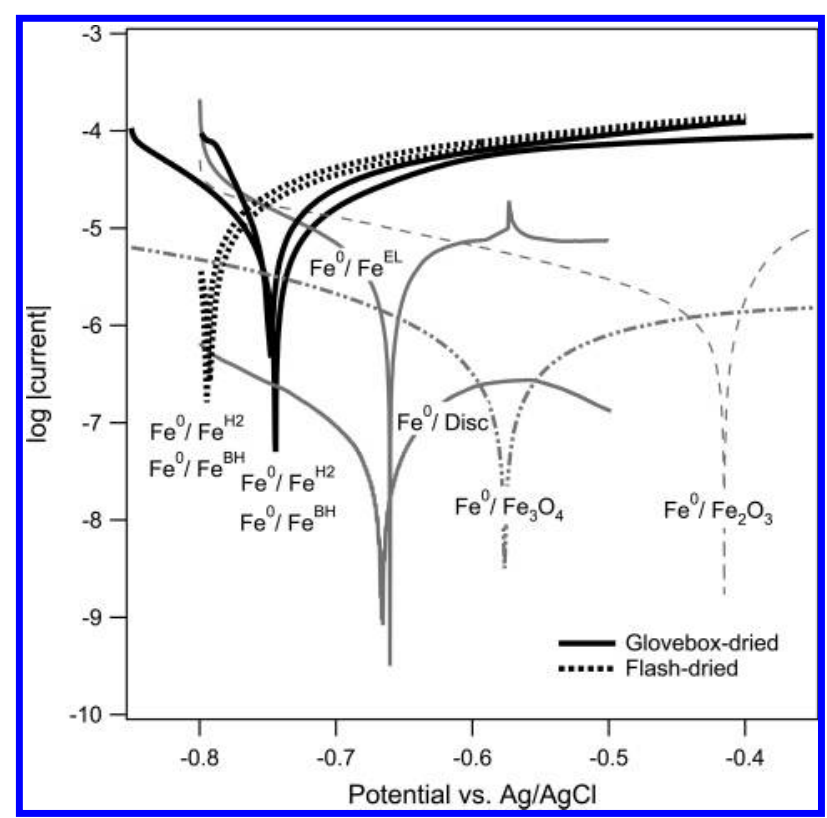

FIGURE 3. Log absolute current vs potential plot from anodic polarization of stationary powder disk electrodes packed with various iron and iron oxide powders. At scan rate $=0.1 \mathrm{mV} / \mathrm{s}$ in anoxic aqueous borate (pH 8.4).

STXM was used to measure the L-edge X-ray absorption near edge structure (XANES) to give spatially resolved chemical state information on the Fe absorbers in the samples. The spectral information obtained by this method is particularly sensitive to oxidation states because of the strong dipole-allowed L-edge $2 \mathrm{p} \rightarrow 3 \mathrm{~d}$ electronic transition. The XANES data (Supporting Information, Figure S5) show that $\mathrm{Fe}^{\mathrm{BH}}$ is similar to the $\mathrm{Fe}^{0}$ standard, with little oxide peak area (which would appear at slightly higher energy), whereas the XANES for $\mathrm{Fe}^{\mathrm{H} 2}$ has broader peaks that suggest iron oxide as well as $\mathrm{Fe}^{0}$. In addition, the area-to-area variation of the XANES was greater for $\mathrm{Fe}^{\mathrm{H} 2}$ than for $\mathrm{Fe}^{\mathrm{BH}}$, which is consistent with the XRD and TEM data (Table 2), confirming that there are separate metal and oxide iron phases in the $\mathrm{Fe}^{\mathrm{H} 2}$ material.

Electrochemical Properties. During preliminary testing of the reproducibility of anodic polarization voltammograms obtained with our powder disk electrodes (PDEs), we found that $\mathrm{Fe}^{\mathrm{H} 2}$ that had been allowed to dry under our glovebox atmosphere gave currents that declined steadily over a period of 14 days (Figure S6). However, flash-dried $\mathrm{Fe}^{\mathrm{H} 2}$ gave anodic polarization voltammograms that were reproducible over 20 days (Figure S7), so all further electrochemical characterizations were performed with PDEs made from flash-dried powders. Even with flash-dried $\mathrm{Fe}^{\mathrm{H} 2}$, consecutive voltammograms obtained with the same PDE showed a decreasing current response. To determine if this behavior is due to passivation by reaction with the electrolyte or potential driven transformation of the electrode material, we exposed the PDE packed with $\mathrm{Fe}^{\mathrm{H} 2}$ to borate solution ( $\mathrm{pH}$ 8.4) for various amounts of time before recording the anodic polarization voltammogram. After $1 \mathrm{~h}$ of exposure in borate, the current response decreased, indicating that the loss of electrochemical response was due to solution driven passivation (Figure S8). Since solution driven passivation cannot be overcome in our system, all further polarization experiments were initiated immediately after the electrode was put in solution.

All of the above experiments provide a baseline from which we can interpret and compare the electrochemical results of the nano- $\mathrm{Fe}^{0}$ materials. Figure 3 shows the anodic polarization voltammograms obtained with PDEs of the nano-Fe ${ }^{0}$ materials, several powder iron oxides, and $\mathrm{Fe}^{\mathrm{EL}}$. For reference, data obtained with a polished disk $\mathrm{Fe}^{0}$ electrode are also included in the figure. As expected, the conventional $\mathrm{Fe}^{0}$ disk electrode and $\mathrm{Fe}^{\mathrm{EL}} \mathrm{PDE}$ gave anodic polarization voltammograms that reflect the transition from the active to passive state of iron as the potential becomes more anodic, which is typical for $\mathrm{Fe}^{0}$ in borate buffer $(51-54)$. A prominent feature of the log current vs potential plot for these electrodes is the singularities where net current is zero (i.e., the corrosion potential; $\left.E_{\text {corr }}\right)$. The conventional $\mathrm{Fe}^{0}$ disk and the $\mathrm{Fe}^{\mathrm{EL}} \mathrm{PDE}$ give $E_{\text {corr }}$ values that are very similar to each other and also to the literature value for $\mathrm{Fe}^{0}$ in borate $(51-54)$. The anodic polarization voltammograms for $\mathrm{Fe}_{3} \mathrm{O}_{4}$ and $\mathrm{Fe}_{2} \mathrm{O}_{3}$ PDE's give $\mathrm{E}_{\text {corr }}$ values more anodic than the $\mathrm{Fe}^{0}$ disk and $\mathrm{Fe}^{\mathrm{EL}} \mathrm{PDE}$. This is not surprising, given that $\mathrm{Fe}_{3} \mathrm{O}_{4}$ is a mixed oxide containing $\mathrm{Fe}^{2+}$ and $\mathrm{Fe}^{3+}$ and that $\mathrm{Fe}_{2} \mathrm{O}_{3}$ contains only $\mathrm{Fe}^{3+}$. Thus, it appears that our experimental design is sensitive to the oxidation state of the iron used in the fabrication of the working electrode in that the material with the most oxidized iron gives the most anodic $E_{\text {corr }}$ relative to $\mathrm{Fe}^{0}$ and $\mathrm{Fe}^{\mathrm{EL}}$.

Figure 3 also shows two sets of anodic polarization voltammograms for the two nano- $\mathrm{Fe}^{0}$ materials $\left(\mathrm{Fe}^{\mathrm{H} 2}\right.$ and $\mathrm{Fe}^{\mathrm{BH}}$ ). The solid lines represent $\mathrm{Fe}^{\mathrm{H} 2}$ and $\mathrm{Fe}^{\mathrm{BH}}$ after they were dried in the anaerobic chamber. The most striking difference is that the $E_{\text {corr }}$ values for both materials are shifted cathodically relative to the $E_{\text {corr }}$ of $\mathrm{Fe}^{0}$ and $\mathrm{Fe}^{\mathrm{EL}}$ and that the $E_{\text {corr }}$ values for the nano materials are very similar to one another. Recall, from experiments mentioned above that $\mathrm{Fe}^{\mathrm{H} 2}$ dried in the anaerobic chamber gave decreasing current response; therefore, more stable and representative results are expected with flash-dried material. The $E_{\text {corr }}$ values for flash-dried $\mathrm{Fe}^{\mathrm{H} 2}$ and $\mathrm{Fe}^{\mathrm{BH}}$ are shifted even more cathodically relative to the $\mathrm{Fe}^{0}$ and $\mathrm{Fe}^{\mathrm{EL}}$ electrodes (Figure 3). The shift in $E_{\text {corr }}$ must reflect disproportionate changes in the kinetics of the coupled half-reactions that determine $E_{\text {corr }}$ in this system: anodic dissolution of $\mathrm{Fe}^{0}$ and the reduction of water. Exactly how electrode material (i.e., conventional $\mathrm{Fe}^{0}$ disk vs our nano$\mathrm{Fe}^{0} \mathrm{PDE}$ ) affects the kinetics of these half-reactions is still under investigation, but it is likely to involve the high surface areas of the nano- $\mathrm{Fe}^{0}$ powders, which often have large surface concentrations of edges, corners, and other defect sites.

Batch Results. Two model contaminants were used as probe compounds to investigate the reactivity of nano- $\mathrm{Fe}^{0}$ with solutes: benzoquinone (BQ) and carbon tetrachloride (CT). BQ was chosen because it is a well-established probe for the reactivity of iron oxides $(55,56)$, and CT has been used in many detailed studies of the reactivity of iron and iron oxides (e.g., refs $57-64$ ). BQ is likely to form comparatively strong inner-sphere complexes on iron and iron oxides (at $\mathrm{pH}>7$, as is relevant to this study; 56), whereas CT is believed to form weak and outer-sphere complexes with oxide-coated iron (65). BQ is labile to reduction by electron transfer (ET) and hydrogen atom transfer (HT), and both pathways will produce mainly hydroquinone (HQ). In contrast, while CT is believed to react mainly by ET in systems containing $\mathrm{Fe}^{0}(66,67)$, branching among two pathways of ET produces diagnostic products: chloroform (CF) for the "1-electron pathway" and methane, carbon monoxide, or formate for the "2-electron pathway" $(58,61,68)$. Since the latter are the preferred products-from the perspective of remediation-any nano-size effect on branching between these two reaction pathways is of practical as well as fundamental interest.

For BQ, pseudo-first-order disappearance rate constants were obtained from the concentration versus time data (not shown), and the results were used to calculate mass normalized rate constants $\left(k_{\mathrm{M}}, \mathrm{L} \mathrm{g}^{-1} \mathrm{~min}^{-1}\right)$. Assuming a range of $\rho_{\mathrm{a}}$ for each type of nano- $\mathrm{Fe}^{0}$, we calculated surface areanormalized rate constants $\left(k_{\mathrm{SA}}, \mathrm{L} \mathrm{m}^{-2} \mathrm{~min}^{-1}\right)$ for each value of $k_{\mathrm{M}}$. The results are summarized in Figure 4, which allows comparisons between types of iron, over ranges of $\rho_{\mathrm{a}}$ (note that changes in assumed $\rho_{\mathrm{a}}$ causes points to move vertically 


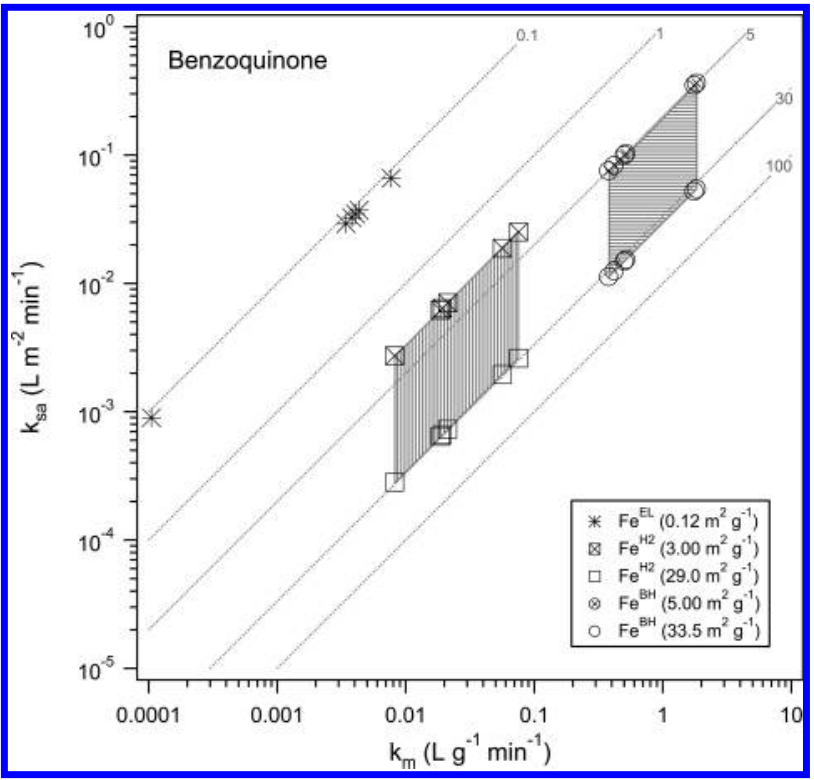

FIGURE 4. Surface area normalized rate constants $\left(k_{\mathrm{SA}}\right)$ vs mass load normalized rate constants $\left(k_{\mathrm{M}}\right)$, for disappearance of benzoquinone (BO) in batch experiments. Diagonal lines are contours for representative values of $\rho_{\mathrm{a}}\left(\mathrm{m}^{2} \mathrm{~g}^{-1}\right)$. For both types of nano-Fe ${ }^{0}, \boldsymbol{k}_{\mathrm{SA}}$ is shown for high and low $\rho_{\mathrm{a}}$ values (given in the legend). High values of $\rho_{\mathrm{a}}$ are from Table 1. Low values or $\rho_{\mathrm{a}}$ are BET measurements from this study. The resulting ranges of rate constants are shaded.

on the plot) and variations in experimental conditions for a particular type of iron (initial $\mathrm{C}_{0}$ values, $\mathrm{pH}$, mixing rate, etc., which cause the data to distribute diagonally along the contour for the assumed value of $\rho_{\mathrm{a}}$ ). For the whole range of conditions tested, the trend in $k_{\mathrm{M}}$ is $\mathrm{Fe}^{\mathrm{EL}}<\mathrm{Fe}^{\mathrm{H} 2}<\mathrm{Fe}^{\mathrm{BH}}$. With respect to $k_{\mathrm{SA}}$, the data in Figure 4 show that $\mathrm{Fe}^{\mathrm{EL}} \approx \mathrm{Fe}^{\mathrm{H} 2}<$ $\mathrm{Fe}^{\mathrm{BH}}$ for the whole range of plausible values of $\rho_{\mathrm{a}}$. The greater reactivity of $\mathrm{Fe}^{\mathrm{BH}}$ (vs $\mathrm{Fe}^{\mathrm{H} 2}$ ) with $\mathrm{BQ}$ is consistent with the more metallic composition of $\mathrm{Fe}^{\mathrm{BH}}$, but the role of other factors (e.g., the B-rich shell material and very small crystallite size) is unknown. The products formed from BQ were the same for all three types of iron: HQ was the only identified product, and it gave mass balance with respect to the amount of $B Q$ reacted.

Figure S9 shows TEM micrographs of flash-dried $\mathrm{Fe}^{\mathrm{BH}}$ (A and $\mathrm{B}$ ) and $\mathrm{Fe}^{\mathrm{H} 2}(\mathrm{C}$ and $\mathrm{D})$ after reaction with $\mathrm{BQ}$. The lower magnification images (A and $\mathrm{C}$ ) demonstrate that some particles appear unaltered even after substantial reaction with BQ (cf., Figures 1-2). Of particular note is that the thickness of the coating on the $\mathrm{Fe}^{\mathrm{BH}}$ particles appears similar to what was observed before reaction, and none of the unreacted particles show "disrupted" shells. It is likely that the microstructure of the B-rich shell material plays a key role in the relative reactivity of $\mathrm{Fe}^{\mathrm{BH}}$. Higher-resolution images (Figure S9B,D) demonstrate that the solid-state reaction products are nanocrystalline and appear to be well-separated from the parent particles, which suggests that the products are formed by oxidative dissolution followed by precipitation. Lattice fringe measurements and diffraction patterns show that the main product is maghemite/magnetite (with some goethite, in the case of $\mathrm{Fe}^{\mathrm{BH}}$ ).

The kinetic data obtained with CT show somewhat different trends than were obtained with BQ. Figure 5 shows $k_{\mathrm{SA}}$ versus $k_{\mathrm{M}}$ for CT, calculated with the same ranges of $\rho_{\mathrm{a}}$ that were used for Figure 4 . Clearly, $k_{\mathrm{M}}$ for reduction of CT is larger with nano- $\mathrm{Fe}^{0}$ than micro- $\mathrm{Fe}^{0}\left(\mathrm{Fe}^{\mathrm{EL}}<\mathrm{Fe}^{\mathrm{H} 2} \approx \mathrm{Fe}^{\mathrm{BH}}\right)$. The relative values of $k_{\mathrm{SA}}$ vary, however, depending on the assumed values of $\rho_{\mathrm{a}}$. For high $\rho_{\mathrm{a}}$, it appears that $\mathrm{Fe}^{\mathrm{EL}}>\mathrm{Fe}^{\mathrm{H} 2}$ $\approx \mathrm{Fe}^{\mathrm{BH}}$; but for low $\rho_{\mathrm{a}}, \mathrm{Fe}^{\mathrm{EL}} \approx \mathrm{Fe}^{\mathrm{H} 2} \approx \mathrm{Fe}^{\mathrm{BH}}$. Thus, given the difficulties in determining accurate (and relevant) values of

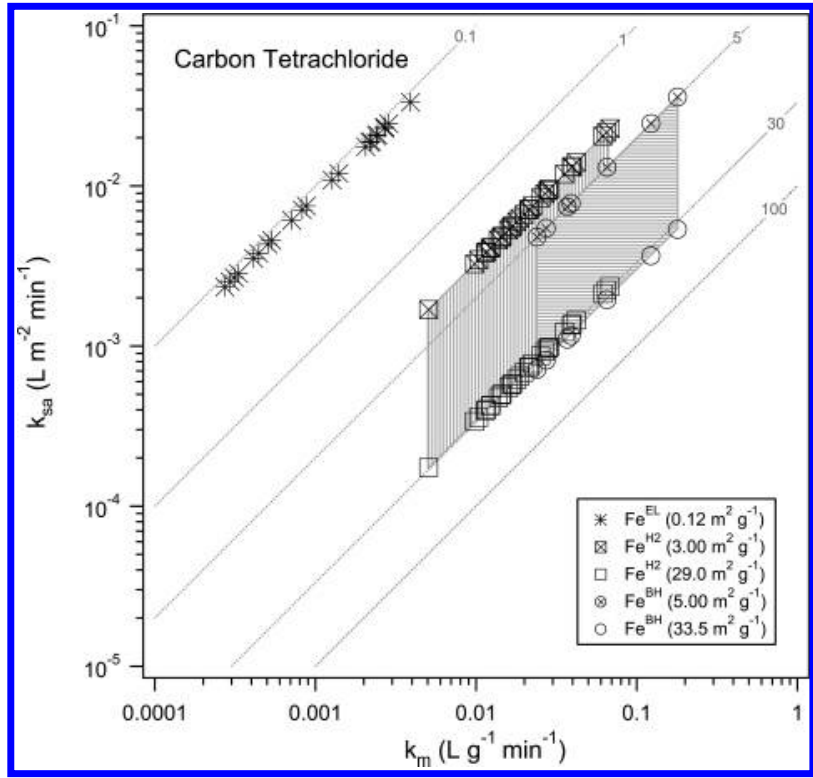

FIGURE 5. Surface area-normalized rate constants vs mass loadnormalized rate constants for the disappearance of carbon tetrachloride (CT). Diagonal lines are contours for representative values of $\rho_{\mathrm{a}}\left(\mathrm{m}^{2} \mathrm{~g}^{-1}\right)$. For both types of nano- $\mathrm{Fe}^{0}, \boldsymbol{k}_{\mathrm{SA}}$ is shown for high and low $\rho_{\mathrm{a}}$ values (given in the legend). High values of $\rho_{\mathrm{a}}$ are from Table 1. Low values or $\rho_{\mathrm{a}}$ are BET measurements from this study. The resulting ranges of rate constants are shaded.

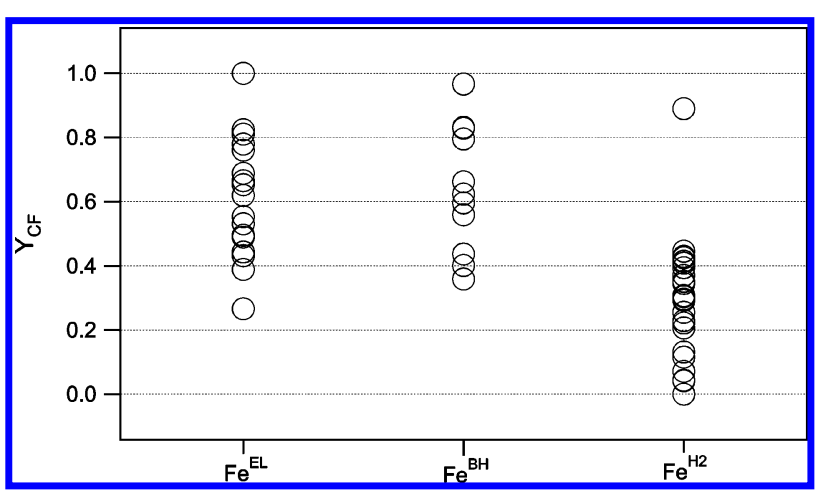

FIGURE 6. Yield of chloroform ( $\left.Y_{\mathrm{CF}}\right)$ vs iron type $\left(\mathrm{Fe}^{\mathrm{EL}}, \mathrm{Fe}^{\mathrm{BH}}, \mathrm{Fe}^{\mathrm{H} 2}\right)$. The range of $Y_{\mathrm{CF}}$ for each iron type reflects the wide range of experimental conditions tested $(\mathrm{pH}$, buffer, age and handling of iron, etc.).

$\rho_{\mathrm{a}}$ for nano- $\mathrm{Fe}^{0}$, it is unclear whether there is a nano-size effect on the surface area-normalized rate constants for reduction of CT. This conclusion holds over the whole range of experimental conditions tested (initial CT concentration, buffer type, $\mathrm{pH}$, and sample handling), the effects of which are represented by the range of data along the contours in Figure 5. The conclusion that nano- $\mathrm{Fe}^{0}$ may not be more reactive than micro- $\mathrm{Fe}^{0}$ on a surface area normalized basis does not necessarily contradict prior claims that nano- $\mathrm{Fe}^{0}$ is more reactive than micro- $\mathrm{Fe}^{0}$ on a per mass basis. It does, however, demonstrate the importance of clearly defining the basis of comparison. Of course, if mass transport (across the stagnant boundary layer or some passivating surface layer) were rate limiting under the conditions of the batch experiments performed in this study, this could mask differences in the intrinsic reactivity of surface sites. We do not think mass transport effects are significant in this study because we observed no change in $k_{\mathrm{SA}}$ with $\mathrm{rpm}>15$ (data not shown); however, subtle mass transport effects might be revealed by further study with more sensitive methods $(63,69)$.

Figure 6 shows the yield of $\mathrm{CF}\left(Y_{\mathrm{CF}}\right)$-one measure of the branching between the one- and two-electron pathways for 


\begin{tabular}{|c|c|c|c|c|}
\hline \multicolumn{5}{|c|}{ TABLE 4. Mass Balance Data for CT and Products ${ }^{a}$} \\
\hline particle prep. & $\mathrm{CCl}_{4}$ & $\mathrm{CHCl}_{3}$ & $\mathrm{CH}_{2} \mathrm{Cl}_{2}$ & unknown \\
\hline \multicolumn{5}{|c|}{$\mathrm{Fe}^{\mathrm{H} 2}$} \\
\hline as-received & 54.2 & 21.7 & 0.0 & 24.1 \\
\hline flash-dried & 58.3 & 18.4 & 0.0 & 23.3 \\
\hline \multicolumn{5}{|c|}{$\mathrm{Fe}^{\mathrm{BH}}$} \\
\hline as-received & 28.8 & 34.8 & 0.7 & 36.7 \\
\hline flash-dried & 15.8 & 39.3 & 2.4 & 42.5 \\
\hline
\end{tabular}

reduction of $\mathrm{CT}$ - -for the same experiments included in Figure 5. In general, the values of $Y_{\mathrm{CF}}$ are $>0.4$ for $\mathrm{Fe}^{\mathrm{EL}}$ and $\mathrm{Fe}^{\mathrm{BH}}$ but are $<0.4$ for $\mathrm{Fe}^{\mathrm{H} 2}$. It is not yet clear why $\mathrm{Fe}^{\mathrm{H} 2}$ gives such a low, and favorable, $Y_{\mathrm{CF}}$, but this result is likely to be due to (i) the $\mathrm{Fe}_{3} \mathrm{O}_{4}$ shell on $\mathrm{Fe}^{\mathrm{H} 2}$, (ii) the reduced $\mathrm{S}$ on the surface of $\mathrm{Fe}^{\mathrm{H} 2}$, and/or (iii) the $\mathrm{B}$ associated with $\mathrm{Fe}^{\mathrm{BH}}$. The first possibility is supported by the low values of $Y_{\mathrm{CF}}$ that have been reported for suspensions of nano-sized $\mathrm{Fe}_{3} \mathrm{O}_{4}$ (61). Previous studies of $\mathrm{CT}$ reduction by $\mathrm{FeS}(70)$, showed that $\mathrm{CF}$ was a major product, with $\mathrm{CS}_{2}$ being a notable minor product, neither of which were observed in this study with $\mathrm{Fe}^{\mathrm{H} 2}$. In Figure 6, as in Figure 5, the range of results for each type of $\mathrm{Fe}^{0}$ reflects the effects of buffer type, $\mathrm{pH}$, and sample handling, which helps to establish the significance of the difference between $Y_{\mathrm{CF}}$ for $\mathrm{Fe}^{\mathrm{H} 2}$ relative to the two other types of $\mathrm{Fe}^{0}$.

To determine what products other than CF were formed, it was necessary to perform batch experiments at high initial CT concentration $(0.86-2.4 \mathrm{mM})$ with a variety of analytical methods, as appropriate for the range of anticipated products. Typical results from headspace GC/MS, shown in Table 4, suggest that $\mathrm{CF}$ was the major product for $\mathrm{Fe}^{\mathrm{H} 2}$ and $\mathrm{Fe}^{\mathrm{BH}}$, that $\mathrm{CH}_{2} \mathrm{Cl}_{2}$ is a minor product, and that a significant portion of the CT reacted to undetermined products. Although not reflected in Table 4, GC/TCD analysis of these samples also showed trace quantities of $\mathrm{CH}_{4}(<0.1 \mathrm{vol} \%)$ in the $\mathrm{Fe}^{\mathrm{BH}}$ samples, whereas no $\mathrm{CH}_{4}$ was detected in the $\mathrm{Fe}^{\mathrm{H} 2}$ samples. No $\mathrm{CS}_{2}, \mathrm{CO}_{2}$, or $\mathrm{CO}$ was detected in the headspace products of either material. Little difference was noted between the as-received and flash-dried samples. In other experiments (not shown), small amounts of formate $\left(1-5 \mu \mathrm{M}\right.$ at $C_{0}=4$ $\mu \mathrm{M}, 5-11 \mu \mathrm{M}$ at $\left.C_{0}=862 \mu \mathrm{M}\right)$ were detected, but these quantities are not enough to close the mass balance for CT degraded. Recall that formate is produced through the "2electron" pathway. These data indicate that at low $\mathrm{C}_{0}$ values, the 2-electron pathway may be favored over the 1-electron pathway. We are still left with a large fraction of carbon that has not been detected, however, and further studies are ongoing to determine all of the products formed under these experimental conditions.

Implications. Data from this paper demonstrate that the two types of nano- $\mathrm{Fe}^{0}$ used in this study are composed of particles with a core/shell structure and that the shells are composed of passivating or protective phases that impart stability to the particles in aqueous suspensions. For $\mathrm{Fe}^{\mathrm{H} 2}$, the shell is mainly iron oxide, whereas for $\mathrm{Fe}^{\mathrm{BH}}$ the shell is composed of iron and boron oxides. Flash-drying these materials - to remove water and solutes-generally had little effect on the properties studied, again suggesting passivation of the particles.

Despite their stability with respect to aqueous corrosion and other solvent-driven dissolution processes, both types of nano- $\mathrm{Fe}^{0}$ react rapidly with $\mathrm{BQ}$ and CT. Although the rate constants for these reactions are large when normalized to iron mass, the surface area-normalized rate constants are similar for nano- and micro-sized $\mathrm{Fe}^{0}$. The apparent lack of an "intrinsic" nano-size effect may reflect the difficulty in defining or measuring the (relevant) specific surface area for highly reactive materials whose properties change with time and environmental conditions. Nevertheless, our results suggest that the extraordinarily high contaminant degradation rates that have often been ascribed to nano- $\mathrm{Fe}^{0}$ are mostly due to the large amount of surface area used in laboratory tests with these materials. In contrast, it appears that nano- $\mathrm{Fe}^{0}$ can have a profound effect on the distribution of products formed from contaminant degradation. In particular, the low yield of chloroform from carbon tetrachloride that was obtained with $\mathrm{Fe}^{\mathrm{H} 2}$ suggests the possibility of an effective new chemical technology for remediation of carbon tetrachloride contaminated groundwater.

\section{Acknowledgments}

Samples of nano iron were donated by C. Clausen (University of Central Florida), K. Okinaka (Toda Kogyo Corp.), and W.$\mathrm{X}$. Zhang (Lehigh University). This work was supported by the U.S. Department of Energy (DOE) Environmental Management Sciences Program and the Office of Energy Research, Office of Basic Energy Sciences, Chemical Sciences Division. Parts of the work were conducted in the William R. Wiley Environmental Molecular Sciences Laboratory (EMSL) and the Advanced Light Source (ALS). We thank EMSL staff Mark Engelhard, David McCready, and Cathy Chin for assistance with the XPS, XRD, and BET analysis, respectively. EMSL is a DOE User Facility operated by Battelle for the DOE Office of Biological and Environmental Research. The Pacific Northwest National Laboratory is operated for the DOE under Contract DE-AC06-76RLO 1830. The ALS is supported by DOE Contract DE-AC03-76SF00098 to Lawrence Berkeley National Laboratory.

\section{Supporting Information Available}

Additional data from X-ray diffraction (XRD), transmission electron microscopy (TEM), X-ray photoelectron spectroscopy (XPS), scanning transmission X-ray spectroscopy (STXM), and voltammetry. This material is available free of charge via the Internet at http://pubs.acs.org.

\section{Literature Cited}

(1) Tratnyek, P. G.; Scherer, M. M.; Johnson, T. J.; Matheson, L. J. Permeable reactive barriers of iron and other zero-valent metals. In Chemical Degradation Methods for Wastes and Pollutants: Environmental and Industrial Applications; Tarr, M. A., Ed.; Marcel Dekker: New York, 2003; pp 371-421.

(2) Glazier, R.; Venkatakrishnan, R.; Gheorghiu, F.; Walata, L.; Nash, R.; Zhang, W.-X. Nanotechnology takes root. Civil Eng. 2003, $73,64-69$.

(3) Elliott, D. W.; Zhang, W.-X. Field assessment of nanoscale bimetallic particles for groundwater treatment. Environ. Sci. Technol. 2002, 35, 4922-4926.

(4) Geiger, C.; Clausen, C. A.; Brooks, K.; Clausen, C.; Huntley, C.; Filipek, L. B.; Reinhart, D. D.; Quinn, J.; Krug, T.; O'Hara, S.; Major, D. Nanoscale and microscale iron emulsions for treating DNAPL. In Chlorinated Solvent and DNAPL Remediation: Innovative Strategies for Subsurface Cleanup; Henry, S. M., Warner, S. D., Eds.; American Chemical Society: Washington, DC, 2003; ACS Symposium Series 837; pp 132-140.

(5) Wang, C.-B.; Zhang, W.-X. Synthesizing nanoscale iron particles for rapid and complete dechlorination of TCE and PCBs. Environ. Sci. Technol. 1997, 31, 2154-2156.

(6) Lien, H.-L.; Zhang, W.-X. Transformation of chlorinated methanes by nanoscale iron particles. J. Environ. Eng. 1999, 125, $1042-1047$.

(7) Xu, Y.; Zhang, W.-X. Subcolloidal Fe/Ag particles for reductive dehalogenation of chlorinated benzenes. Ind. Eng. Chem. Res. 2000, 39, 2238-2244.

(8) Lien, H.-L.; Zhang, W.-X. Nanoscale iron particles for complete reduction of chlorinated ethenes. Colloid Surf. A 2001, 191, 97105.

(9) Lowry, G. V.; Majetich, S.; Sholl, D.; Tilton, R. D.; Matyjaszewski, K.; Liu, Y.; Sarbu, T.; Almusallam, A.; Redden, G. D.; Meakin, P.; Rollins, H. W. Preprint Extended Abstracts, Divison of Environmental Chemistry, 227th National Meeting, March 28-Apri1 l, 
2004, Anaheim, CA; American Chemical Society: Washington, DC, 2004; Vol. 44, No. 1, pp 488-493.

(10) Lowry, G. V.; Johnson, K. M. Congener-specific dechlorination of dissolved PCBs by microscale and nanoscale zerovalent iron in a water/methanol solution. Environ. Sci. Technol. 2004, 38, $5208-5216$

(11) Choe, S.; Chang, Y. Y.; Hwang, K. Y.; Khim, J. Kinetics of reductive denitrification by nanoscale zero-valent iron. Chemosphere 2000, 41, 1307-1311.

(12) Ponder, S. M.; Darab, J. G.; Mallouk, T. E. Remediation of Cr(VI) and $\mathrm{Pb}(\mathrm{II})$ aqueous solutions using supported, nanoscale zerovalent iron. Environ. Sci. Technol. 2000, 34, 2564-2569.

(13) Li, F.; Vipulanandan, C.; Mohanty, K. K. Microemulsion and solution approaches to nanoparticle iron production for degradation of trichloroethylene. Colloid Surf. A 2003, 223, $103-112$.

(14) Zhang, W.-X. Nanoscale iron particles for environmental remediation. L. Nanopart. Res. 2003, 5, 323-332.

(15) Johnson, T. L.; Scherer, M. M.; Tratnyek, P. G. Kinetics of halogenated organic compound degradation by iron metal. Environ. Sci. Technol. 1996, 30, 2634-2640.

(16) Klabunde, K. J.; Stark, J.; Koper, O.; Mohs, C.; Park, D. G.; Decker, S.; Jiang, Y.; Lagadic, I.; Zhang, D. J. Nanocrystals as stoichiometric reagents with unique surface chemistry. J. Phys. Chem. 1996, 100, 12142-12153.

(17) Mulvaney, P. Metal nanoparticles: double layers, optical properties, and electrochemistry. In Nanoscale Materials in Chemistrv; Klabunde, K. J., Ed.; Wiley: New York, 2001; pp 121167.

(18) Campbell, C. T.; Parker, S. C. The effect of size-dependent nanoparticle energetics on catalyst sintering. Science 2002, 298, 811-814.

(19) Elliott, S. The Physics and Chemistry of Solids; Wiley \& Sons: New York, 1998.

(20) Brus, L. Electronic wave functions in semiconductor clusters: experiment and theory. L. Phys. Chem. 1986, 90, 2555-2560.

(21) Wang, Y.; Herron, N. Nanometer-sized semiconductor clusters: material synthesis, quantum size effects, and photophysical properties. L. Phvs. Chem. 1991, 95, 525-532.

(22) Klimenkow, M.; Nepijko, S. A.; Kuhlenbeck, H.; Baumer, M.; Schlogl, R.; Fruend, H. J. The structure of Pt-aggregates on a supported thin aluminum oxide film in comparison with unsupported alumina: a transmission electron microscopy study. Surf. Sci. 1997, 391, 27-36.

(23) Nepijko, S. A.; Klimenkow, M.; Kuhlenbeck, H.; Zemlyanov, D.; Herein, D.; Schlogl, R.; Fruend, H. J. TEM study of tantalum clusters of $\mathrm{Al}_{2} \mathrm{O}_{3} / \mathrm{NiAl}(110)$. Surf. Sci. 1998, 412/413, 192-201.

(24) Nepijko, S. A.; Klimenkow, M.; Adelt, M.; Kuhlenbeck, H.; Schlogl, R.; Fruend, H. J. Structural investigation of palladium clusters on $\gamma-\mathrm{AlO}_{3}(111) / \mathrm{NiAl}(110)$ with transmission electron microscopy. Langmuir 1999, 15, 5309-5313.

(25) Gan, S.; Liang, Y.; Baer, D. R.; Sievers, M. R.; Herman, G. S.; Peden, C. H. F. Effect of platinum nanocluster size and titania surface structure upon $\mathrm{CO}$ surface chemistry on platinumsupport on $\mathrm{TiO}_{2}(110)$. J. Phys. Chem. B 2001, 105, 2412-2415.

(26) Baer, D. R.; Burrows, P. E.; El Azab, A. A. Enhancing coating functionality using nanoscience and nanotechnology. Prog. Org. Coat. 2003, 47, 342-356.

(27) Punoose, A.; Magnone, H.; Seehra, M. S.; Bonevich, J. Bulk to nanoscale magnetism and exchange bias in $\mathrm{CuO}$ nanoparticles. Phys. Rev. B 2001, 64, 174420

(28) Sharma, R. K.; Sharma, P.; Maitra, A. Size-dependent catalytic behavior of platinum nanoparticles on the hexacyanoferrate(III)/thiosulfate redox reaction. L. Colloid Interface Sci. 2003, $265,134-140$.

(29) Signorini, L.; Pasquini, L.; Savini, L.; Carboni, R.; Boscherini, F.; Bonetti, E.; Giglia, A.; Pedio, M.; Mahne, N.; Nannarone, S. Sizedependent oxidation in iron/iron oxide core-shell nanoparticles. Phvs. Rev. B 2003, 68, 195423 .

(30) Theil Kuhn, L.; Bojesen, A.; Timmermann, L.; Meedom Nielsen, M.; Morup, S. Structural and magnetic properties of core-shell iron-iron oxide nanoparticles. J.Phys.: Condens. Matter 2002, 14, 13551-13567.

(31) Scherer, M. M.; Balko, B. A.; Tratnyek, P. G. The role of oxides in reduction reactions at the metal-water interface. In MineralWater Interfacial Reactions: Kinetics and Mechanisms; Sparks, D. L., Grundl, T. J., Eds.; ACS Symposium Series 715; American Chemical Society: Washington, DC, 1998; pp 301-322.

(32) Zaitsev, V. S.; Filimonov, D. S.; Presnyakov, I. A.; Gambino, R. J.; Chu, B. Physical and chemical properties of magnetite and magnetite-polymer nanoparticles and their colloidal dispersions. I. Colloid Interface Sci. 1999, 212, 49-57.
(33) Wang, Y.; Wong, J. F.; Teng, X.; Lin, X. Z.; Yang, H. "Pulling" nanoparticles into water: Phase transfer of oleic acid stabilized monodisperse nanoparticles into aqueous solutions of $\alpha$-cyclodextrin. Nano Lett. 2003, 3, 1555-1559.

(34) Schrick, B.; Hydutsky, B. W.; Blough, J. L.; Mallouk, T. E. Delivery vehicles for zerovalent metal nanoparticles in soil and groundwater. Chem. Mater. 2004, 16, 2187-2193.

(35) Uegami, M.; Kawano, J.; Okita, T.; Fujii, Y.; Okinaka, K.; Kakuya, K.; Yatagai, S. Iron particles for purifying contaminated soil or ground water. Process for producing the iron particles, purifying agent comprising the iron particles, process for producing the purifying agent and method of purifying contaminate soil or ground water. Toda Kogyo Corp. U.S. Patent Application, 2003.

(36) Okinaka, K.; Jazdanian, A. D.; Shimizu, H.; Okita, T.; Kakuya, K. Proceedings of the Fourth International Conference on Remediation of Chlorinated and Recalcitrant Compounds, May 2427, 2004, Monterey, CA; Battelle Press: Columbus, OH, 2004 (in press).

(37) Geiger, C. L.; Clausen, C. A.; Brooks, K.; Coon, C.; Huntley, C.; Filipek, L. B.; Devor, R.; Krug, T.; O’Hara, S.; Major, D.; Quinn, J. Preprint Extended Abstracts, Division of Environmental Chemistry, 225th National Meeting, March 23-27, 2003, New Orleans, LA; American Chemical Society: Washington, DC, 2003; Vol. 43, No. 1, pp 939-944.

(38) Lien, H.-L.; Zhang, W.-X. Preprint Extended Abstracts, Division of Environmental Chemistry, 215th National Meeting, Dallas, TX; American Chemical Societv: Washington, DC, 1998; Vol. 38, No. 1, pp 29-30.

(39) Ponder, S. M.; Darab, J. G.; Bucher, J.; Caulder, D.; Craig, I.; Davis, L.; Edelstein, N.; Lukens, W.; Nitsche, H.; Rao, L.; Shuh, D. K.; Mallouk, T. E. Surface chemistry and electrochemistry of supported zerovalent iron nanoparticles in the remediation of aqueous metal contaminants. Chem. Mater. 2001, 13, 479-486.

(40) Schrick, B.; Blough, J. L.; Jones, A. D.; Mallouk, T. E. Hydrodechlorination of trichloroethylene to hydrocarbons using bimetallic nickel-iron nanoparticles. Chem. Mater. 2002, 14, $5140-5147$.

(41) Liu, Y.; Lowry, G. Preprint Extended Abstracts, Divison of Environmental Chemistry, 228th National Meeting, August 2226, 2004, Philadelphia, PA; American Chemical Society: Washington, DC, 2004; Vol. 44, No. 2, pp 412-417.

(42) Matson, D. W.; Linehan, J. C.; Darab, J. G.; Buehler, M. F.; Phelps, M. R.; Neuenschwander, G. G. A flow-through hydrothermal method for the synthesis of active nanocrystalline catalysts. In Advanced Techniques in Catalyst Preparation; Moser, W. R., Ed.; Academic: New York, 1996; pp 259-283.

(43) Matson, D. W.; Linehan, J. C.; Darab, J. G.; Buehler, M. F. Nanophase iron-based liquefaction catalysts: synthesis, characterization, and model compound reactivity. Energv Fuels 1994 $8,10-18$

(44) Miehr, R.; Tratnyek, P. G.; Bandstra, J. Z.; Scherer, M. M.; Alowitz M.; Bylaska, E. J. The diversity of contaminant reduction reactions by zero-valent iron: role of the reductate. Environ. Sci. Technol. 2004, 38, 139-147.

(45) Pecher, K.; McCubbery, D.; Kneedler, E.; Rothe, J.; Bargar, J.; Meigs, G.; Cox, L.; Nealson, K.; Tonner, B. Quantitative charge analysis of manganese biominerals in aqueous suspension using scannning transmission X-ray microscopy (STXM). Geochim. Cosmochim. Acta 2003, 67, 1089-1098.

(46) Nurmi, J. T.; Bandstra, J. Z.; Tratnyek, P. G. Packed powde electrodes for characterizing the reactivity of granular iron in borate solutions. J. Electrochem. Soc. 2004, 151, B347-B353.

(47) Drazic, D. M.; Zecevic, S. K. Transient phenomena during the anodic polarization of iron. Corros. Sci. 1985, 25, 209-216.

(48) Vaughan, G. M.; Mopper, K. Determination of nanomolar levels of formate in natural-waters based on a luminescence enzymatic assay. Anal. Chim. Acta 1990, 231, 299-303.

(49) Glavee, G. N.; Klabunde, K. J.; Sorensen, C. M.; Hadjipanayis, G. C. Chemistry of borohydride reduction of iron(II) and iron(III) ions in aqueous and nonaqueous media - formation of nanoscale $\mathrm{Fe}, \mathrm{FeB}$, and $\mathrm{Fe}_{2} \mathrm{~B}$ powders. Inorg. Chem. 1995, 34, 28-35.

(50) Carpenter, E. E.; Calvin, S.; Stroud, R. M.; Harris, V. G. Passivated iron as core-shell nanoparticles. Chem. Mater. 2003, 15, 32453246.

(51) Sato, N. The passivity of metals and passivating films. In Passivity of Metals; Frankenthal, R. P., Kruger, J., Eds.; Electrochemical Society: Princeton, NJ, 1978; pp 29-58.

(52) Cohen, M. Passivity and breakdown of passivity on iron. In Passivity of Metals; Frankenthal, R. P., Kruger, J., Eds.; Electrochemical Society: Princeton, NJ, 1978; pp 521-545. 
(53) Jovancicevic, V.; Kainthla, R. C.; Tang, Z.; Yang, B.; Bockris, J. $\mathrm{O}$. M. The passive film on iron: an ellipsometric-spectroscopic study. Langmuir 1987, 3, 388-395.

(54) Oblonsky, L. J.; Devine, T. M. A surface enhanced Raman spectroscopic study of the passive films formed in borate buffer on iron, nickel, chromium and stainless steel. Corros. Sci. 1995, $37,17-41$.

(55) Stack, A. G.; Eggleston, C. M.; Englehard, M. H. Reaction of hydroquinone with hematite. I. Study of adsorption by electrochemical-scanning tunneling microscopy and X-ray photoelectron spectroscopy. J. Colloid Interface Sci. 2004, 274, 433441.

(56) Kung, K.-H.; McBride, M. B. Electron-transfer processes between hydroquinone and hausmannite $\left(\mathrm{Mn}_{3} \mathrm{O}_{4}\right)$. Clavs Clav Miner. 1988, 36, 303-309.

(57) Balko, B. A.; Tratnyek, P. G. Photoeffects on the reduction of carbon tetrachloride by zero-valent iron. J. Phvs. Chem. B 1998, 102, 1459-1465.

(58) Elsner, M.; Haderlein, S. B.; Kellerhals, T.; Luzi, S.; Zwank, L.; Angst, W.; Schwarzenbach, R. P. Mechanisms and products of surface-mediated reductive dehalogenation of carbon tetrachloride by Fe(II) on goethite. Environ. Sci. Technol. 2004, 38, $2058-2066$.

(59) Gaspar, D. J.; Lea, A. S.; Engelhard, M. H.; Baer, D. R.; Miehr, R.; Tratnyek, P. G. Evidence for localization of reaction upon reduction of $\mathrm{CCl}_{4}$ by granular iron. Langmuir 2002, 18, 76887693.

(60) Logue, B. A.; Westall, J. C. Kinetics of reduction of nitrobenzene and carbon tetrachloride at an iron-oxide coated gold electrode. Environ. Sci. Technol. 2003, 37, 2356-2362.

(61) McCormick, M. L.; Adriaens, P. Carbon tetrachloride transformation on the surface of nanoscale biogenic magnetite particles. Environ. Sci. Technol. 2004, 38, 1045-1053.

(62) Pecher, K.; Haderlein, S. B.; Schwarzenbach, R. P. Reduction of polyhalogenated methanes by surface-bound Fe(II) in aqueous suspensions of iron oxides. Environ. Sci. Technol. 2002, 36, 17341741.
(63) Scherer, M. M.; Westall, J. C.; Ziomek-Moroz, M.; Tratnyek, P. G. Kinetics of carbon tetrachloride reduction at an oxide-free iron electrode. Environ. Sci. Technol. 1997, 31, 2385-2391.

(64) Támara, M.; Butler, E. C. Effects of iron purity and groundwater characteristics on rates and products in the degradation of carbon tetrachloride by iron metal. Environ. Sci. Technol. 2004, $38,1866-1876$.

(65) Johnson, T. L.; Fish, W.; Gorby, Y. A.; Tratnyek, P. G. Degradation of carbon tetrachloride by iron metal: Complexation effects on the oxide surface. J. Contam. Hydrol. 1998, 29, 377-396.

(66) Scherer, M. M.; Westall, J. C.; Tratnyek, P. G. Discussion on "Electrochemical and Raman spectroscopic studies of the influence of chlorinated solvents on the corrosion behaviour of iron in borate buffer and in simulated groundwater" [Corros. Sci. 2000, 42, 1921-1939]; Corros. Sci. 2001, 44, 1151-1157.

(67) Li, T.; Farrell, J. Electrochemical investigation of the rate-limiting mechanisms for trichloroethylene and carbon tetrachloride reduction at iron surfaces. Environ. Sci. Technol. 2001, 35, 35603565.

(68) Tratnyek, P. G.; Amonette, J. E.; Bylaska, E. J. Preprint Extended Abstracts, Divison of Environmental Chemistry, 227th National Meeting, March 28-April 1, 2004, Anaheim, CA; American Chemical Society: Washington, DC, 2004; Vol. 44, No. 1, pp $456-460$

(69) Scherer, M. M.; Johnson, K.; Westall, J. C.; Tratnyek, P. G. Mass transport effects on the kinetics of nitrobenzene reduction by iron metal. Environ. Sci. Technol. 2001, 35, 2804-2811.

(70) Kriegman-King, M. R.; Reinhard, M. Transformation of carbon tetrachloride by pyrite in aqueous solution. Environ. Sci. Technol. 1994, 28, 692-700.

Received for review May 31, 2004. Revised manuscript received September 9, 2004. Accepted September 27, 2004. 